\title{
УUCTEUTBOBHABCTBO
}

\author{
УДК 7.071.1(477)(092):78.087.6 \\ DOI https://doi.org/10.24919/2308-4863/34-5-3
}

\begin{abstract}
Марія СТАДНИЦЬКА,
orcid.org/0000-0001-8234-4867

аспірант кафедри методики музичного виховання і диригування Дрогобицького державного педагогічного університету імені Івана Франка

(Дрогобич, Львівська область, Україна) azaz239993@gmail.com
\end{abstract}

\section{ЕВОЛЮЦІЯ КОМПОЗИТОРСЬКОГО ПИСЬМА У ВОКАЛЬНІЙ ЛІРИЦІ ВІКТОРА МАТЮКА}

\begin{abstract}
У статті зроблено спробу иілісного розгляду вокальної творчості Віктора Матюка шляхом огляду тематики, жанрової специфіки та засобів музичної виразності його вокальних творів. Простежено еволючію композиторського письма у вокальній ліриці, розкрито прийоми композиторського письма, творчий доробок В. Матюка в изарині вокальної музики в еволюиійному процесі; визначено місце композитора в розвитку різних жанрів української вокальної музики; охарактеризовано жанрово-стильову специифіку вокальної творчості мития, а також засоби музичної поетики його вокальних творів; розглянуто вокальну творчість В. Матюка в аспекті еволюиї стилю мития, зокрема вивчених під кутом їх музичної поетики, мелодї, гармонії, ритміки, музичної форми, фактури, жанрової основи, драматургї та музично-виконавської стилістики.

Визначено образно-тематичну сферу поезії, особливості ї̈ музичного прочитання, структуру музичних творів, характерні закономірності музичного викладу. Художньо-виховний потенціал вокальної спадщини В. Матюка трунтуються на таких характерних ознаках: глибина і гуманістична спрямованість художнього змісту, прагнення глибоко та правдиво відтворити в музиці літературний текст, опора на фольклорну основу; тонка психологізація музичних образів, виразне їх образно-емоційне розгортання; розмайття жанрово-стильової палітри; естетична довершеність музичної мови.

Прослідковано еволюиію композиторського письма, особливості індивідуального стилю та вплив сольної вокальної спадщини на творчість майбутнього покоління галицьких композиторів. В. Матюк - один із першопрохідиів у становленні украӥнського ліричного солоспіву на галицьких теренах кінця XIX-початку XX ст. Проаналізовано еволюцію композиторського доробку В. Матюка в контексті національної хорової традиції з урахуванням його власних засад. Обгрунтовано риси індивідуального композиторського стилю мития, специфічні прикмети його творчості, зумовлені багатогранністю діяльності.
\end{abstract}

Ключові слова: В. Матюк, вокальна лірика, еволючія композиторського письма, засоби музичної виразності.

\section{Mariia STADNYTSKA, orcid.org/0000-0001-8234-4867 \\ Graduate Student at the Department of Methods of Music Education and Conducting Drohobych Ivan Franko State Pedagogical University (Drohobych, Lviv region, Ukraine) azaz239993@gmail.com}

\section{EVOLUTION OF COMPOSER'S LETTER IN VOCAL LYRICS BY VICTOR MATIUK}

The article is an attempt at a holistic review of Victor Matyuk's vocal work of themes, genre specifics and musical expression of his vocal works. The evolution of composer's writing in vocal lyricism is traced, the methods of composer's writing are revealed. V. Matyuk's creative work in the field of vocal music in the evolutionary process is revealed. The place of the composer in the development of various genres of Ukrainian vocal music is determined. The genre-style specifics of the artist's vocal creativity are characterized, as well as the means of musical poetics of his vocal works. $V$. Matyuk's vocal creativity in the aspect of evolution of the artist's style is considered.

In particular, vocal creativity was studied from the angle of their musical poetics, melody, harmony, rhythmics, musical form, texture, genre basis, drama and musical-stylistic stylistics. The figurative-thematic sphere of poetry, features of its musical reading, structure of musical works and characteristic regularities of musical presentation are determined. $V$. Matyuk's vocal heritage, artistic and educational potential, which is based on such characteristic features as: depth and humanistic orientation of artistic content, the desire to deeply and truthfully reproduce a literary text in music, reliance on folklore; subtle psychologization of musical images, their expressive figurative and emotional development; variety of genre and style palette; aesthetic perfection of musical language.

The evolution of composer's writing, features of individual style and influence of solo vocal heritage on creativity of the future generation of Galician composers are traced. V. Matyuk is one of the pioneers in the formation of Ukrainian 
lyrical solo singing in Galicia in the late XIX - early XX century. The evolution of V. Matyuk's compositional work in the context of the national choral tradition is analyzed taking into account his own principles. The features of the artist's individual compositional style, specific features of his work, which are due to the versatility of the artist's activity, are substantiated.

Key words: V. Matyuk, vocal lyrics, evolution of composer's writing, means of musical expression.

Постановка проблеми. Творча діяльність Віктора Матюка - священика, композитора, педагога, визначного музично-громадського діяча невід'ємний складник української музичної культури. Незважаючи на важливий композиторський доробок, у дослідженні його творчості все ще залишається багато «білих плям». Насамперед це стосується вокально-хорових творів. Вони хоча i увійшли до репертуарного списку виконавських колективів і зайняли гідне місце в українському музичному просторі, однак майже не були предметом уваги українських музикознавців.

Аналіз досліджень. Описуючи душпастирські служіння, Р. Кухар наголошував, що В. Матюк «умів поєднати службу Богові зі службою рідному народові своєю вірною духовною опікою, виховно-освітнім проводом і великим талантом музичного творця» (Кухар, 1989: 785). Життя та творчість В. Матюка були предметом уваги українських музикознавців Й. Волинського, Ю. Булки, Л. Кияновської, Л. Мазепи, Н. Костюк, І. Бермес, О. Миронової та інших.

Широке коло питань, пов'язаних із творчою діяльністю митця, висвітлюється у роботах Й. Волинського, М. Черепанина, М. Білинської, М. Возняка, С. Івасейка. Останніми роками спостерігається посилення інтересу науковців до діяльності українського духовенства, зокрема композиторів-священиків Галичини XIX ст., їхнього композиторськогодоробку,втомучислійВ.Матюка.

Мета статті полягає у простеженні музичностильової специфіки вокальних творів В. Матюка в аспекті еволюції його стилю.

Виклад основного матеріалу. Соціальноісторична й політична ситуація в Галичині XIX початку XX ст. не сприяла розвиткові національної музичної культури, однак жанр солоспіву (як i хоровий) отримав значну когорту його творців. Популярність салонного романсу, пісні стимулювали тогочасних композиторів працювати саме в такому напрямі. Значну роль у цьому процесі відігравали священичі родини, які були осередками культурного та мистецького життя Галичини.

В. Матюк (1852-1912 рр.) - композитор-аматор, теоретик, збирач народних пісень і колядок. Як син дяка він змалку виявив велику любов до музики, співав у церкві не тільки ритуальні співи, але й сольні твори М. Вербицького. І. Лаврів- ського та інших композиторів. Володіючи дуже гарним голосом, юнак брав участь у різних мистецьких заходах Львова, Перемишля, спілкувався з відомими співаками того часу: Мишугою, Мельницьким, Закревським.

Короткі уроки композиції, контрапункту та інструментовки під керівництвом П. Бажанського не могли дати В. Матюкові грунтовних знань для професійної творчості. Його раннім композиторським спробам притаманна як гармонійна, так і мелодична спрощеність («Прошу я тя, любий сину», «Розлука»). «Матюк належав до тієї генерації українських композиторів, яка плекала форму сольної пісні з особливим замилуванням. Він написав кілька десятків пісень, надзвичайно часто виконуваних останніми десятиліттями XIX ст., 3 яких збереглося до наших часів ледве вісім» (Бермес, 2012: 184).

До кращих i популярних ліричних пісень В. Матюка можна зарахувати солоспіви «Крилець», «Чом так скритно», «Під осінь», «Нещасний». Однак простота вокальної мелодії, гармонії у супроводі, а також невимоглива фактура акомпанементу його солоспівів, які свого часу користувалися значною популярністю, не змогли витримати професійної перевірки часом. У 22 роки композитор створює чи не найкращий солоспів «Веснівка» (1874 р., інша назва «Цвітка дрібная») до слів М. Шашкевича, присвячений о. П. Бажанському. Наскрізна форма пісні найкраще відповідає побудові поезії. Це оригінальний твір, у якому народні мотиви не простежуються.

Першим виконавцем цієї сентиментальної й милозвучної пісні став О. Мишуга, який дав ій славний і довгий сценічний шлях, що триває й нині. За твердженням Л. Кияновської «цей ранній твір акумулював у собі не лише стилістичні особливості, а й більш універсальні, світоглядні позиції, які збереглися навіть до пізньої творчості композитора» (Кияновська, 2007: 242). Солоспіви В. Матюка «Згадка щастя» (1877 р.) на слова Гушалевича в рукописному варіанті «Гадка щастя» (архів ЛНБ ім. В. Стефаника) суттєво відрізняється від твору, виданого в посібнику М. Логойди «Вокальні камерні твори українських композиторів» (Львів: Спів Митуси, 2005).

У 40-х роках XX ст. цей твір викликав зацікавлення С. Людкевича, який збагатив фактурно 
супровід, редагував поетичний текст відповідно до сучасної української мови. Незмінною залишилася вокальна партія, зручно викладена В. Матюком, адже йому, як вправному співакові, ця сторона вокальних композицій вдалася бездоганно. У редакції С. Людкевича солоспів отримав розгорнуту побудову, експресивну кульмінацію, а різнопланові емоційні настрої концептуально відрізнили «Згадку щастя» від попередніх вокальних композицій В. Матюка (Логойда, 2005: 5-6).

Чотири пісні, написані у 1879 р., можуть слугувати як дослідницький матеріал. Твір «Коб так в єдинеє слово» написаний у формі da саро. При скромній гармонії акомпанементу із одноманітною ритмічною фігурою позитивною стороною солоспіву $є$ «тісне пристосування музики до поезії як під оглядом розміщення більших і менших цезур, так і акцентації» (Логойда, 2005: 11-12). Пісні «Ти маєш бриллянти і перли» (куплетної форми), «Ти, дівчино злотоуста» (простої тричастинної форми), «Ой плакав я в просонню» (наскрізної форми 3 варіаційними рисами) не набули еволюційного творчого розвитку композиторського письма В. Матюка. Дещо кращим зразком може слугувати ще один твір, присвячений О. Мишузі з нагоди від’їзду співака до Італії у 1880 р. Це пісня «3 слезою в оці відійду» на слова Гушалевича. Наскрізна форма твору, в якому об'єднуючою ланкою стали фортепіанні епізоди, за побудовою частково подібна до «Гадки щастя».

Остання пісня В. Матюка «Ти, дівчино чорноброва» (1882 р.) не отримала визнання. Найкращим його зразком виявився солоспів «Веснівка», написаний композитором у молодому віці. За словами С. Людкевича «кожний зразок Матюкової мелодії має «щось» своє, питоме. Його головні прикмети - се наївна простота виразу з відтінком природного сентименту, а декуди легкої меланхолії. Його пісня має якийсь питомий, хоч як простий сенс, становить живу частину особистого, неподільного «я» автора» (Людкевич, 1999: 273).

Висновки. Узагальнити композиторську спадщину В. Матюка поки що складно 3 огляду на те, що багато творів знаходяться в рукописах, а духовні та дитячі пісні розосереджені по збірочках в співаниках. За біобібліографією I. Бермес можна орієнтовно проаналізувати кількісний вимір збережених композицій митця, якому належить близько 90 хорових творів (оригінальних та опрацювань), в тому числі богослужбові композиції та релігійні пісні (близько 50), світські твори на поезіi I. Гушалевича, Б. Кирчіва, М. Шашкевича та інших (близько 40); понад 20 дитячих пісень (для соло, дуету); 8 солоспівів на вірші I. Гушалевича, В. Шашкевича (переспіви 3 Г. Гайне), М. Шашкевича; вокальний дует; коломийка для інструментального ансамблю; сценічні твори, жанрову належність яких сам композитор визначав по-різному: опера («Нещасна любов», «Капрал Тимко»), оперета («Інвалід»), драма («Наші поселенці»). Низка композицій, які могли б суттєво доповнити творчість митця, є не знайденою. Йдеться про оперу «Довбуш», музику до драми «Простак» за В. Гоголем, кантату «Гамалія» на слова Т. Шевченка.

Одним із перших охарактеризував стиль i творчу манеру митця С. Людкевич у статті 1912 p. «Віктор Матюк», зауважуючи про відсутність систематизації спадщини В. Матюка i неповноту власних висновків. Автор підкреслював деяку однобічність творчості композитора, обмеженої сольними та хоровими піснями, які $є$ «самостійними чи зложеними в мелодрами» (Людкевич, 1999: 272). С. Людкевич зазначав і про цілісність стилю, простоту, своєрідну оригінальність виразових засобів, природний сентименталізм і щирість музичного виразу. «Його головні прикмети - се наївна простота виразу з відтінком природного сентименту (далекого від усякої манери та пересади), а подекуди легкої меланхолії», - узагальнював власні висновки автор (Людкевич, 1999: 496).

Характеристику мислення композитора дещо доповнив Витвицький, вказуючи, що «як композитор Матюк не був новатором-пробоєвиком у нашій музиці минулого століття» (Витвицький, 1937: 13). У своїй статті науковець звертає увагу на такі прикмети творчості митця: природний та органічний синтез різних впливів, перевага вокальних форм, продумане голосоведення у хоровій фактурі, старанне ставлення до поетичного тексту, ясність і невибагливість музичної мови.

М. Загайкевич у монографії «Музичне життя Західної України другої половини ХІХ ст.» розглядає творчість В. Матюка крізь призму традиціоналізму та як зв'язкову ланку між творчістю М. Вербицького і наступним періодом. Прикладні потреби тогочасного музикування в Галичині зумовили, на думку дослідниці, жанрові характеристики спадщини митця. Авторка також звертає увагу на віддалення музичного стилю від фольклорних джерел, натомість інтенсивними були впливи мелосу побутової пісні-романсу і західноєвропейського солоспіву. «Хоч Матюк талантом і розмахом творчої ініціативи значно поступався своєму вчителю М. Вербицькому, проте він дещо розширив засоби «перемишльської школи», впровадив більшу вільність та інтонаційну виразність мелодики, голосоведення, значно відійшов від 
статичності ритмічного руху, яка надавала музиці західноукраїнських композиторів деякого хорального забарвлення», - підсумовувала М. Загайкевич (Загайкевич, 1960: 195).

У дослідженні Л. Кияновської В. Матюк постає композитором-аматором доби «загального прагнення до професіоналізму», а також «романтиком-еклектиком» і прихильником традиційних принципів творчості, цінність якої базувалася на національних дидактичних і прикладних потребах. «Пряма залежність творчих планів із просвітницькими, суспільними осередками, до яких був наближений автор, - це теж ознака тієї «кульмінації аматорства» в Галичині, насамперед просвітницько-суспільної ролі, яку визначає собі митець, обмежуючи сферу своїх творчих інтересів», зазначено у монографії «Галицька музична культура XIX - XX століття» (Кияновська, 2000: 339).

Один із першопрохідців у становленні українського ліричного солоспіву на галицьких теренах кінця XIX - початку XX ст. В. Матюк, відчуваючи потребу свого часу, реалізував власний музичний талант саме в цьому жанрі. Глибоко досліджуючи тему, Л. Кияновська підсумовує: «Заслуга В. Матюка полягає і в тому, що він одним із перших проклав нові стежки в жанрі камерно-вокальної лірики, на яких згодом розквітне вокальна музика композиторів наступних поколінь (В. Барвін- ський, С. Людкевич, Н. Нижанківський), оскільки фактично жанр солоспіву був ще майже «недоторканою цілиною» в галицькій музичній культурі» (Кияновська, 2007: 66).

Вокальна спадщина В. Матюка містить великий художньо-виховний потенціал, який грунтується на таких характерних ознаках: глибина i гуманістична спрямованість художнього змісту, прагнення глибоко та правдиво відтворити в музиці літературний текст, опора на фольклорну основу; тонка психологізація музичних образів, виразне їх образно-емоційне розгортання; розмаїття жанрово-стильової палітри; естетична довершеність музичної мови.

В. Матюк $є$ однією 3 характерних постатей культури Галичини у другій половині XIX ст., він зробив важливий внесок у становлення композиторської школи національних традицій і професійності в українській музиці того часу. Будучи священиком і працюючи у зрілий період здебільшого по селах, він прагнув своєю музичною творчістю і багатовекторною просвітницькою працею піднести музично-освітній рівень найширших верств суспільства. Подальші дослідження з цієї тематики можуть окреслювати проблеми духовного виховання не тільки школярів (засобами музичного мистецтва), але й студентів середніх і вищих навчальних закладів освіти.

\section{СПИСОК ВИКОРИСТАНИХ ДЖЕРЕЛ}

1. Бермес I. Михайло Вербицький і Віктор Матюк: спадкоємець художньо-естетичних традицій. Вісник Прикарпатського наиіонального університету ім. І. Стефаника. Серія: Мистеитвознавство. 2012. Вип. 24-25. С. 183-189.

2. Витвицький В. Віктор Матюк: українська музика. Львів. 1937, Ч. 2. С. 13.

3. Загайкевич М. Музичне життя Західної України другої половини ХІХ ст. Київ, 1960. С. 192.

4. Кияновська Л. Перемишльська школа як культурологічний феномен. Вісник Львівського національного університету ім. І. Франка. Серія: Мистещтввознавство. 2007. Вип. 7. С. 65-71.

5. Кияновська Л. Галицька музична культура XIX - XX ст. : навчальний посібник. Тернопіль : СМП. Астон, 2000. C. 339.

6. Кияновська Л. Галицька музична культура XIX - XX століття : навч. посібник. Чернівці : Книги-XXI, 2007. C. 424.

7. Кухар Р. Отець Віктор Матюк - душпастир і композитор (1852-1912) Надбужанщина - Нью-Йорк - Париж Сідней - Торонто. 1989. В 2 т. Т. 2. С. 784-786.

8. Логойда М. Вокальні камерні твори українських композиторів: В. Матюк, О. Нижанківський, Я. Ярославенко, М. Скорик, О. Козаренко. Текст, ноти. Спів Митуси. Львів, 2005. С. 5-6, 11-12.

9. Людкевич С. Дослідження, статті, рецензії, виступи / упоряд. 3. Штундер. Львів : Вид-во М. Коць, 1999. Т. 1. C. $270-273$.

10. Людкевич С. Дослідження, статті, рецензії, виступи / упоряд. З. Штундер. Львів : Вид-во М. Коць, 1999. T. 1. C. 496

\section{REFERENCES}

1. Bermes I. Mykhailo Verbytskyi i Viktor Matiuk: spadkoiemets khudozhno-estetychnykh tradytsii. [Mykhailo Verbytsky and Viktor Matyuk: heir of artistic and aesthetic traditions]. Bulletin of the Precarpathian University. Art history, 2012. № 24-25, p. 183-189 [in Ukrainian].

2. Vytvytskyi V. Viktor Matiuk. Ukrainska muzyka. [Victor Matyuk. Ukrainian music]. 1937, № 2, p. 13 [in Ukrainian].

3. Zahaikevych M. Muzychne zhyttia Zakhidnoi Ukrainy druhoi polovyny XIX st. [Musical life of Western Ukraine in the second half of the XIX century]. Kyiv, 1960, p. 192 [in Ukrainian].

4. Kyianovska L. Peremyska shkola yak kulturolohichnyi fenomen. [Peremyshl school as a culturological phenomenon]. Bulletin of Lviv National University I. Franko. Ser. Art history, 2007, № 7, p. 65-71 [in Ukrainian]. 
5. Kyianovska L. Halytska muzychna kultura XIX - XX st. [Galician musical culture of the XIX - XX centuries]. Tutorial : Ternopil. SMP Aston, 2000, p. 339 [in Ukrainian].

6. Kyianovska L. Halytska muzychna kultura XIX - XX stolittia. [Galician musical culture of the XIX - XX centuries]. Chernivtsi : Books-XXI, 2007, p. 424 [in Ukrainian].

7. Kukhar R. Otets Viktor Matiuk - dushpastyr i kompozytor (1852-1912). Nadbuzhanshchyna. [Father Viktor Matyuk was a pastor and composer (1852-1912) of Nadbužany.] - Niu-York - Paryzh - Sydnei - Toronto. 1989, № 2 (2), p. 784-786 [in Ukrainian].

8. Lohoida M. Vokalni kamerni tvory ukrainskykh kompozytoriv: V. Matiuk, O. Nyzhankivskyi, Ya. Yaroslavenko, M. Skoryk, O. Kozarenko. Tekst, noty. Spiv Mytusy. [Vocal chamber works by Ukrainian composers: V. Matyuk, O. Nyzhankivsky, J. Yaroslavenko, M. Skoryk, O. Kozarenko. Text, notes. Singing Myths], Lviv, 2005, p. 5-6, 11-12 [in Ukrainian].

9. Liudkevych S. Viktor Matiuk. Doslidzhennia, statti, retsenzii, vystupy. [Research, articles, reviews, speeches] uporiad. Z. Shtunder, Lviv, publishing house M. Kots, 1999. T. 1, p. 270-273 [in Ukrainian].

10. Liudkevych S. Doslidzhennia, statti, retsenzii, vystupy. [Research, articles, reviews, speeches] u 2 t. Lviv publishing house M. Kots, 1999. T. 1, p. 496 [in Ukrainian]. 